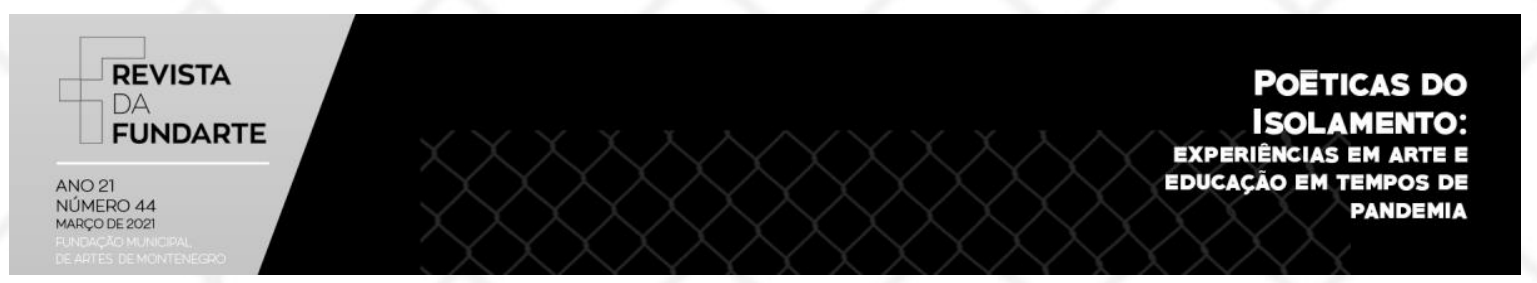

\title{
CORPO QUE COLA, CORPO QUE CRIA: ENSAIO-COLLAGE DE UM APRENDER SOMÁTICO EM ISOLAMENTO
}

Gustavo Monteiro Tessler ${ }^{1}$

Resumo: O presente ensaio versa sobre o corpo isolado, suas possibilidades de encontro e aprendizado. Tensiona-se as relações entre corpo e espaço na medida em que a pandemia de COVID-19 atua como fator limitante. Relata-se uma experiência em Arte e Educação desenvolvida ao longo do ano de 2020, transitando das aulas presenciais ao Ensino Remoto Emergencial. Apresentase como collage, como encontro de fragmentos desta experiência. Não se busca aqui esgotar nada. Busca-se metamorfosear as faltas em transbordamentos. Busca-se a criação como forma de se construir um futuro potente desde o agora. Por menos certezas e muito mais aberturas de caminhos, encontros, ideias.

Palavras-chave: Educação Somática; Ensino; Potência criativa.

\section{BODY THAT GLUES, BODY THAT CREATES: ESSAY-COLLAGE OF A SOMATIC LEARNING IN ISOLATION}

\begin{abstract}
This essay deals with the body in isolation, its possibilities of meeting and learning. The relations between body and space are strained as the COVID-19 pandemic acts as a limiting factor. It reports an experience in Arts and Education developed during the year of 2020, moving from classrooms to Emergency Remote Education system. It presents itself as collage, as a meeting of fragments of this experience. There is no attempt here to exhaust anything. It seeks to metamorphose faults into overflows. Creation is sought as a way to build a powerful future from now on. For less certainty and much more openings of paths, meetings, ideas.
\end{abstract}

Keywords: Somatic Education; Teaching; Creative power.

\section{Início do Texto:}

\section{Convite à leitura: quem, quando, como e por que escreve?}

"Por que escrevemos? Irrompe um coro. Porque não podemos somente viver." Patti Smith em Devoção (2019)

\footnotetext{
${ }^{1}$ Licenciado em Geografia pela UFRGS. Aluno dos cursos de Mestrado Acadêmico no Programa de Pós-Graduação em Educação - linha de pesquisa: Arte, Linguagem e Currículo - e de Bacharelado em Geografia, ambos pela mesma universidade.
}

TESSLER, Gustavo Monteiro. Corpo que cola, corpo que cria: ensaio-collage de um aprender somático em isolamento. Revista da FUNDARTE. Montenegro, p.01-18, ano 21, ํㅡ 44, janeiro/março de 2021.

Disponível em: http://.seer.fundarte.rs.gov.br/index.php/revistadafundarte/index> 30 de março de 2021. 


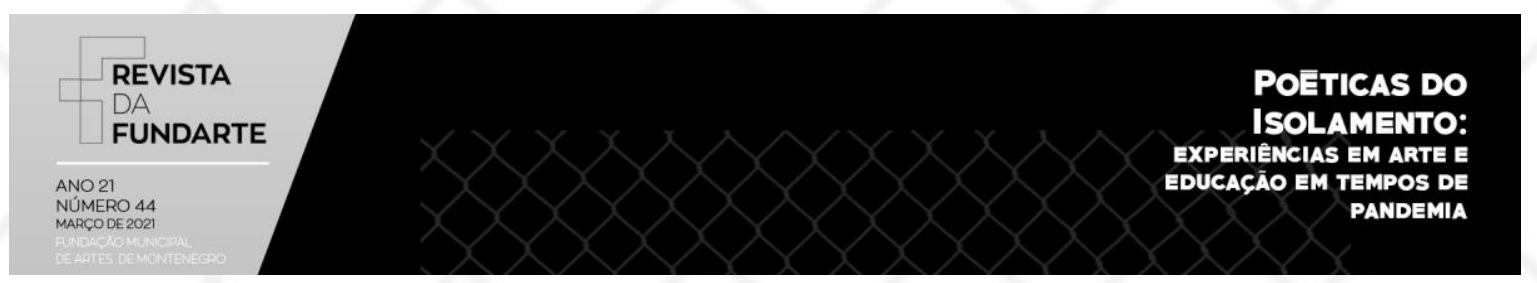

O presente trabalho desenvolve-se em natureza híbrida, apresentando um relato de experiência em arte e educação a partir de uma proposta ensaística. Para o exercício de uma escrita que se pretende como ato de transformação, parte-se da contribuição de Luciana Gruppelli Loponte (2019), na medida em que a autora sugere que busquemos, no exercício da pesquisa em arte e educação, a criação como prática de espaços que valorizem as existências e resistências possíveis em nossas esferas da vida. Neste sentido, aproveita-se do conceito de articulação proposto por Bruno Latour (2008), de maneira que pensemos a ciência colocando em dúvida nossas certezas, evitando cair em redundâncias. Busca-se, sobretudo, a assimilação de novas perguntas, possibilidades de experimentação.

O que se lê a seguir é fruto de uma acumulação de quase um ano - entre o primeiro fragmento apresentado e a finalização do ensaio. Parte-se, portanto, de um período anterior à chegada da pandemia de COVID-19 no Brasil e conclui-se em um presente ainda pandêmico - considerado inclusive Como um dos períodos mais severos da doença, e ainda sem uma perspectiva de melhora a curto prazo.

Há a combinação de diferentes escalas de análise presentes na conjuntura do que se apresenta. A nível mundial, considera-se o avanço da pandemia no planeta; a nível pessoal, as transformações perceptíveis no corpo, na vida do autor. Atentase também para as inúmeras escalas outras existentes entre as duas anteriormente citadas. Não cabe aqui cairmos em dualismos, mas justamente tentarmos entender que o trabalho é fruto de muitas interferências e sobreposições e afetos.

No que se refere às experiências relatadas, explica-se aqui que estas se originam como fragmentos originados no contexto de uma disciplina de curso de graduação. Especificamente uma disciplina de um curso de Licenciatura em Dança denominada de Estudos Somáticos do Movimento. O primeiro atrevimento que se apresenta vem do fato do autor do trabalho não ser estudante deste curso. À época da matrícula na disciplina, era recém graduado no curso de Licenciatura em Geografia, e mantinha-se vinculado à universidade através do currículo de bacharelado nesta mesma área.

TESSLER, Gustavo Monteiro. Corpo que cola, corpo que cria: ensaio-collage de um aprender somático em isolamento. Revista da FUNDARTE. Montenegro, p.01-18, ano 21, ํㅡㄴ, janeiro/março de 2021.

Disponível em: http://.seer.fundarte.rs.gov.br/index.php/revistadafundarte/index> 30 de março de 2021. 


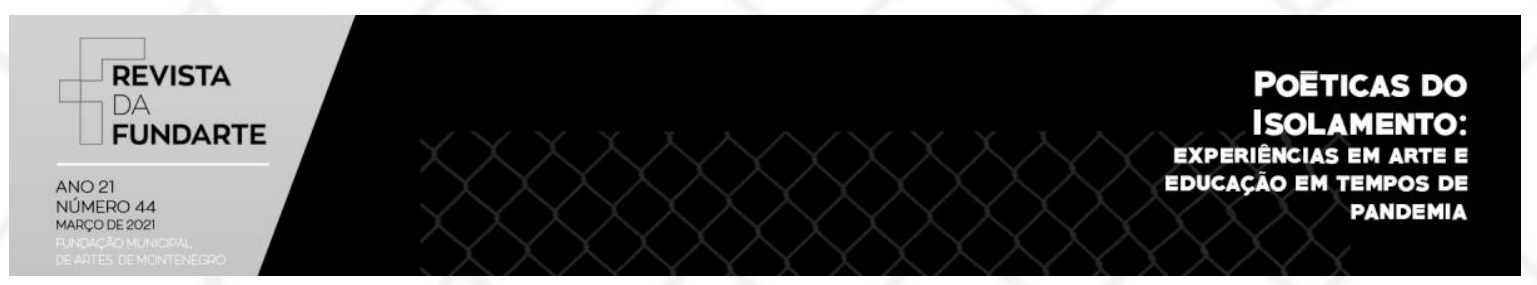

Um segundo atrevimento que se observa diz respeito a como o relato de experiência aqui se constrói. Utiliza-se como inspiração os estudos sobre a collage apresentados por Fernando Fuão (2009). Neles, o autor não pretende ensinar uma técnica, mas sim fomentar possibilidades para novos desdobramentos sobre esta. Neste sentido, o presente trabalho se ampara na sugestão do autor de encarar a collage como encontro, juntando diferentes recortes que juntos experimentam novos significados.

Parte-se da escrita enquanto laboratório criativo. Tendo em mente as vontades de sempre se produzir algo diferente, experimenta-se aqui uma collage de textos e outros disparadores - chamados de fragmentos. Entendendo as condições limitantes impostas pelo necessário isolamento social, ensaia-se articulações possíveis para se estudar [com] o corpo neste contexto. Evidentemente sentimos, neste momento, falta de muitas coisas. Contudo, não se pretende aqui ficar num jogo que lamenta por estas faltas - muito menos conforta-se com eventuais sobras. Busca-se, então, colar ideias, relatos, imagens e devaneios de um possível transbordamento em nossas práticas possíveis no agora. Se ao falarmos de corpo falamos sobre os sistemáticos encontros, na impossibilidade destes, criamos encontros novos através da collage.

Como resultado, tem-se o relato como ensaio-collage: ou seja, é uma collage, apesar de não ser composta exclusivamente por imagens. É um relato, pois se refere a algo específico que se passou. É também uma cartografia, em algumas de suas variadas possibilidades. É o registro possível de uma série de afetos que deixou-se vibrar entre corpos (ROLNIK, 2016). E é também um mapeamento daquilo que foi possível fazer, com uma devida intenção por trás. Assume-se a perspectiva do ensaiocomo a sugerida por Foucault (1988) em $O$ uso dos prazeres - segundo volume da História da Sexualidade. No texto, o autor reitera a importância de nos permitirmos modificar nossas verdades. O ensaio surge, então, como laboratório para estas modificações, como experiência de um pensamento que duvida e cria e duvida novamente.

TESSLER, Gustavo Monteiro. Corpo que cola, corpo que cria: ensaio-collage de um aprender somático em isolamento. Revista da FUNDARTE. Montenegro, p.01-18, ano 21, ㄲo 44, janeiro/março de 2021.

Disponível em: http://.seer.fundarte.rs.gov.br/index.php/revistadafundarte/index> 30 de março de 2021. 


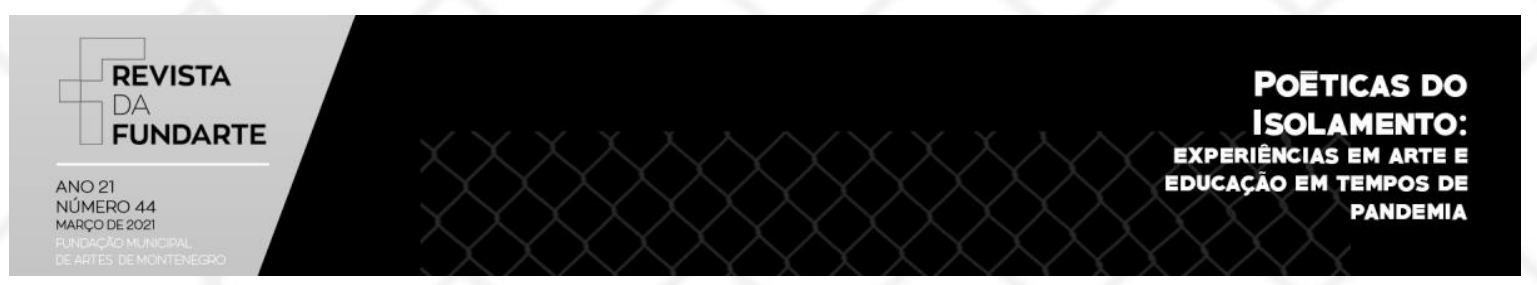

Surge aqui o convite para adentrar ao laboratório, para ensaiar em conjunto. Saboreie os fragmentos, mas com cuidado: a cola que os une pode estar ainda fresca. Se assim os encontrar, então lembre que ainda se pode fazer deles um bom uso. Cole onde achar prudente. Cole onde achar que melhor vibra.

\section{Fragmento-diário: qualquer dia; diferente de um dia qualquer.}

Primeira semana de março de 2020. Primeira semana de aulas do ano.

O despertador toca. Levo um tempo olhando para as paredes e assimilando que há um dia pela frente. A música toca novamente e se torna desagradável preciso fazê-la parar. Enfim me levanto e vou ao banheiro tomar um banho. Pela janela vejo que chove na mesma intensidade que cai água do chuveiro. Tento pensar que roupa botar para sair na chuva, mas não chego a nenhuma conclusão. Volto para o quarto, abro o armário e pego a primeira camiseta da pilha. Vou até a cozinha e boto uma água na chaleira. Enquanto ela não chia, amasso duas ou três bananas, as cubro com granola, uma colherinha de maca peruana e derramo mel por cima de tudo. Viro a água quente sobre o pó de café e deixo o cheiro me aquecer enquanto olho mais um pouco da chuva na janela - é, hoje não vai dar para a bicicleta.

Sentado à mesa, olho qualquer coisa em qualquer aplicativo do celular - não estou prestando atenção mesmo. Penso que meu hábito de fazer o desjejum acompanhado da tela não pode ser saudável. Sendo o primeiro da casa a acordar, reponho a ração da gata - que também ainda dorme. Escovo os dentes e lavo o rosto mais uma vez. Lembro de pegar uns dois livros importantes, além de um caderno que ainda tenha folhas em branco - estes se somam a uma porção de coisas perdidas dentro da bolsa. Sob o guarda-chuva saio de casa rumo à parada de ônibus. Hoje os fios dos fones de ouvido estão particularmente mais difíceis de desemaranhar do que o normal - talvez a vida não esteja tão difícil assim. Com a trilha sonora adequada me sinto pronto para encarar o dia que tenho pela frente. Me

TESSLER, Gustavo Monteiro. Corpo que cola, corpo que cria: ensaio-collage de um aprender somático em isolamento. Revista da FUNDARTE. Montenegro, p.01-18, ano 21, ํㅡㄴ, janeiro/março de 2021.

Disponível em: http://.seer.fundarte.rs.gov.br/index.php/revistadafundarte/index> 30 de março de 2021. 


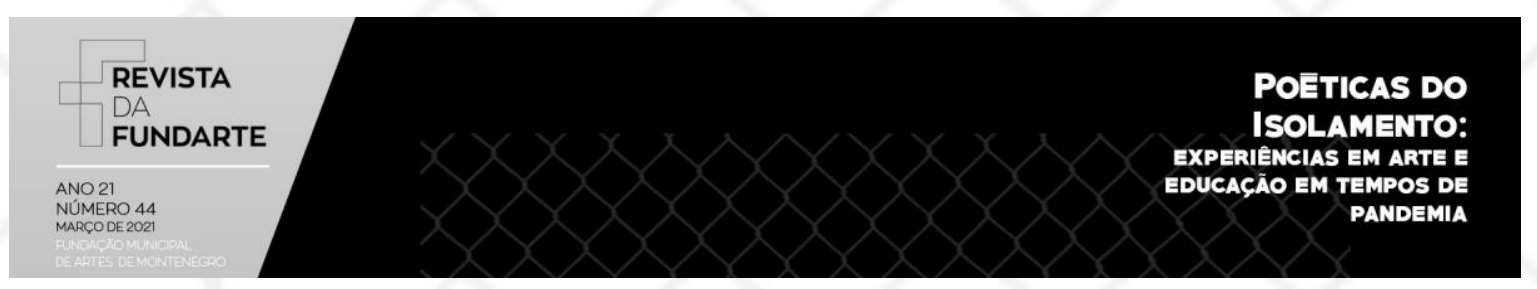

sinto disposto a deixar o corpo vibrar entre os aleatórios encontros de que a vida é feita, como lembro de ler no livro da Suely Rolnik (2016). Por que será que ando nesta fase de me sentir melhor abraçado ao ler não-ficção? Brincando entre duas pedras soltas da calçada, cuido para não molhar ninguém em volta. O ônibus chega. Começa o dia.

\section{[cola]}

Talvez uma das afirmativas mais reproduzidas de Clarice Lispector - ao menos quando consideramos as citações que foram verdadeiramente escritas por ela - seja aquela que dá início à narrativa de $A$ hora da estrela. Ali, a escritora ucraniana-pernambucana afirma: "tudo no mundo começou com um sim. Uma molécula disse sim a outra molécula e nasceu a vida" (LISPECTOR, 1998, p. 11). Clarice parte de uma afirmação sobre o princípio de tudo aquilo que conhecemos - e o faz justo na primeira frase de um romance no qual muito ensaia sobre as incertezas da vida.

Personagem central do livro, a jovem e desterritorializada Macabéa ressignifica objetos e palavras ao longo da história - justamente por partir de um lugar ingênuo mas potente, distante das certezas presentes na vida que a cerca. Pode nos ser útil partir da provocação de Lispector para nos distanciarmos de algumas certezas e passarmos a nos perguntar: quando que passamos a dizer sim para algumas coisas desta vida? Por coisas podemos entender várias delas. Desde o significado de uma palavra à utilidade que nos tem qualquer objeto. Ou mesmo que imagem nos vem à cabeça quando imaginamos uma pessoa ou um lugar existentes ou não no mundo?

Propõe-se este exercício na medida em que se entende que vivemos hoje um momento de profunda ressignificação das coisas todas que nos são presentes. Diferentemente do ressignificar ingênuo de Macabéa, temos agora uma imposição de nos adequarmos a limitações que algum tempo atrás seriam impensáveis. Desde o início do ano de 2020, a pandemia de COVID-19 coloca a humanidade na

TESSLER, Gustavo Monteiro. Corpo que cola, corpo que cria: ensaio-collage de um aprender somático em isolamento. Revista da FUNDARTE. Montenegro, p.01-18, ano 21, ํㅡㄴ, janeiro/março de 2021.

Disponível em: http://.seer.fundarte.rs.gov.br/index.php/revistadafundarte/index> 30 de março de 2021. 


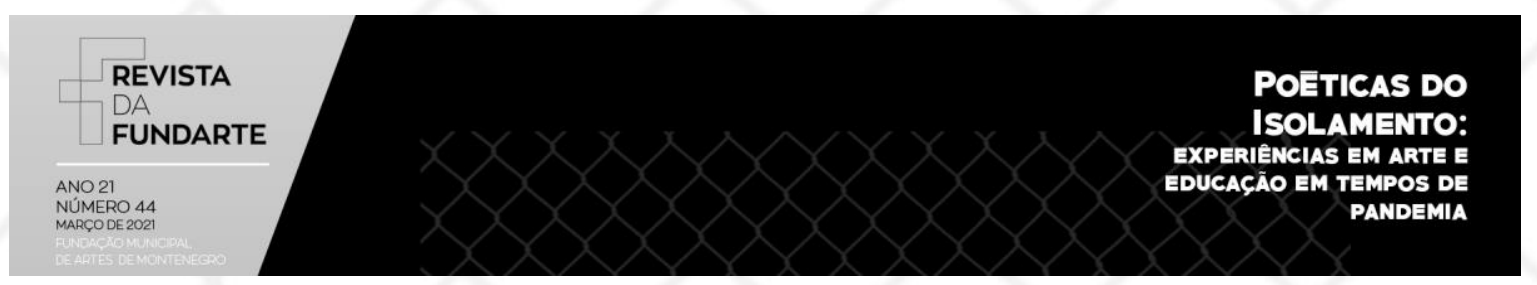

condição de isolamento social. Sendo esta a maneira mais sensata de evitarmos a circulação do vírus, guardemo-nos em nossas casas por tempo ilimitado. Daí a necessidade - e não o desejo propriamente (ESPINOSA, 2020; ROLNIK, 2016) - de darmos novo sentido a uma série de coisas presentes em nosso cotidiano.

Mesa de jantar vira mesa de trabalho; garagem vira academia; bancada de cozinha vira apoio de lousa escolar. Não transformam-se só os espaços, mas para muitas pessoas a madrugada vira hora produtiva; café da manhã vira reunião. Momentos de encontro e gozo são subvertidos: apresentação vira live; aniversário vira videochamada; ensaio vira monólogo. E para tentar lidar com todas estas transformações: cama vira divã - privilégio de quem pode contar com a escuta analítica em tempos nos quais o direito a organizarmos nossos afetos através da palavra parece ser mais uma na lista de tantas perdas.

\section{Fragmento-pergunta: brevíssima questão profunda.}

Após um período de suspensão das atividades, as aulas voltaram a acontecer. Após alguns meses daquelas saudosas duas ou três semanas de aulas presenciais, num longínquo março de 2020, as atividades passam a acontecer com encontros virtuais: o tal do Ensino Remoto Emergencial. As atividades agora passam a ser ora síncronas, ora assíncronas. Juntamente com este embaralhamento do tempo, um embaralhamento também dos espaços. Lembro que, possivelmente em nosso primeiro encontro por chamada de vídeo, um colega perguntou: "profe, quando o Laban propôs os planos ele não esperava que a gente fosse trabalhar com o plano da janela, né?". 2

\footnotetext{
${ }^{2}$ Rudolf Laban, em sua extensa contribuição para os estudos de análise do movimento em dança, propõe algumas maneiras de se entender a orientação do corpo no espaço. Entre elas, estão os planos da porta (altura), da mesa (largura) e da roda (profundidade). Não se pretende aqui versar sobre estas proposições, visto que não se trata aqui de um estudo propriamente labaniano. Introduzse esta observação apenas para marcar a relação que o colega fez destes planos com as janelas virtuais de conversação, típicas das chamadas de vídeo.
}

TESSLER, Gustavo Monteiro. Corpo que cola, corpo que cria: ensaio-collage de um aprender somático em isolamento. Revista da FUNDARTE. Montenegro, p.01-18, ano 21, ํㅡ 44, janeiro/março de 2021.

Disponível em: http://.seer.fundarte.rs.gov.br/index.php/revistadafundarte/index> 30 de março de 2021. 


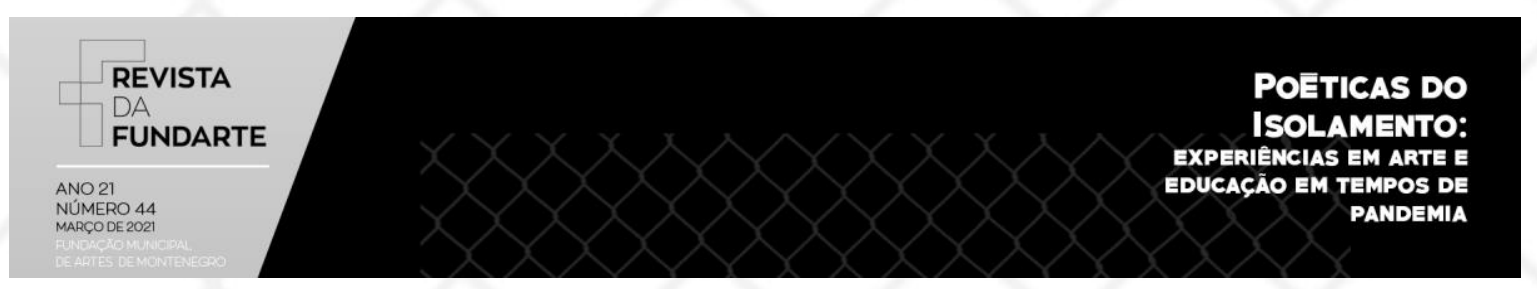

[cola]

Como ampliar, então, as perspectivas deste plano da janela? Distante de assumir um falso otimismo, caricato de uma má interpretação daquilo que foi o movimento hippie, articulam-se algumas proposições a respeito das maneiras que podemos encarar essas mudanças forçadas pela pandemia e seus consequentes isolamentos. Não se trata, pois, de pensar o lado bom desta situação toda, mas sim de encarar de frente o presente que nos é possível. Neste sentido, entende-se que é a partir de agora que construímos o futuro, a perspectiva pós-pandêmica. Afinal, esperar por esta virada não basta. É frustrante a curto prazo, pois sujeita-se à agonia de nunca saber quando a mudança chegará; e também a longo prazo, pois se há alguma certeza sobre o futuro é que ele não será semelhante a projeções feitas a partir de uma postura passiva de contínuo aguardo.

Em um dado momento, foi necessário deixar-se experimentar. A necessidade de ligação do campo somático com as interfaces possíveis entre corpo e natureza se deu a partir das contribuições como as de Ciane Fernandes (2013) e Vera Margarida Lessa Catalão $(2011)^{3}$. Houve especial destaque para o trabalho de Carla Vendramin, a partir de suas propostas de articulação entre a somática e a permacultura, realizado já em situação de isolamento social (VENDRAMIN e CHRISTIE, 2020). Foi proposto, então, que deixássemos vibrar estas possibilidades nos corpos isolados. Mais do que isso, que houvesse uma tentativa de documentar os diálogos possíveis com aquilo que entendemos por natureza, mesmo que de dentro de nossas casas. Foi a brecha que se teve para falar das faltas - afinal, sim, elas existem, e ganham especial potência quando evidenciadas as possibilidades de metamorfoseá-las em transbordamentos.

$O$ fragmento que se apresenta a seguir é, antes de mais nada, um convite. Parte da janela como metáfora. A janela de casa, que olha para o lago; a janela da videochamada; a janela de tempo; Há uma composição de imagens do autor

\footnotetext{
${ }^{3}$ Ambas as autoras citadas são utilizadas no presente trabalho como disparadoras, não cabendo, aqui, uma tentativa de esgotamento de suas propostas.
}

TESSLER, Gustavo Monteiro. Corpo que cola, corpo que cria: ensaio-collage de um aprender somático em isolamento. Revista da FUNDARTE. Montenegro, p.01-18, ano 21, ํㅡㄴ, janeiro/março de 2021.

Disponível em: http://.seer.fundarte.rs.gov.br/index.php/revistadafundarte/index> 30 de março de 2021. 


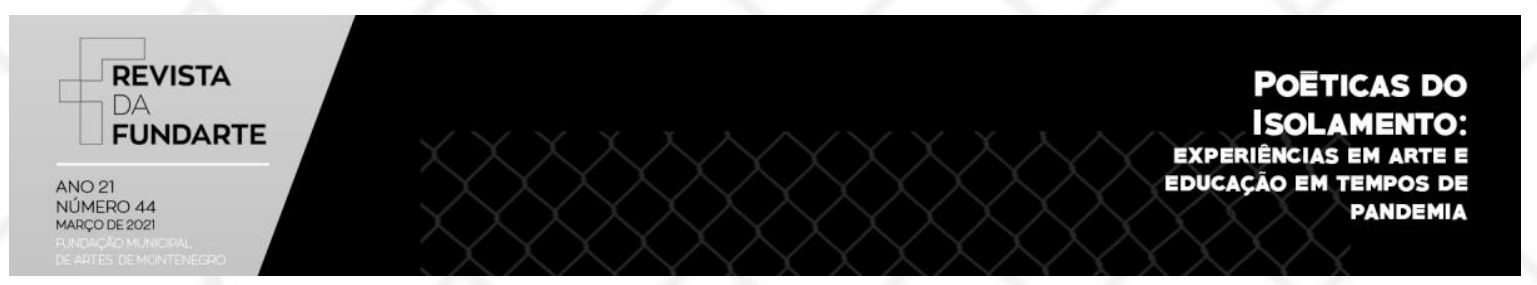

tocando trompete - e processando o som através de uma cadeia de pedais de efeito - com uma sequência de movimentos performáticos que apresentam possibilidades de contato com a natureza existentes hoje, isolado em casa.

\section{Fragmento-atividade: mas e quando se quer falar das faltas? ${ }^{4}$}

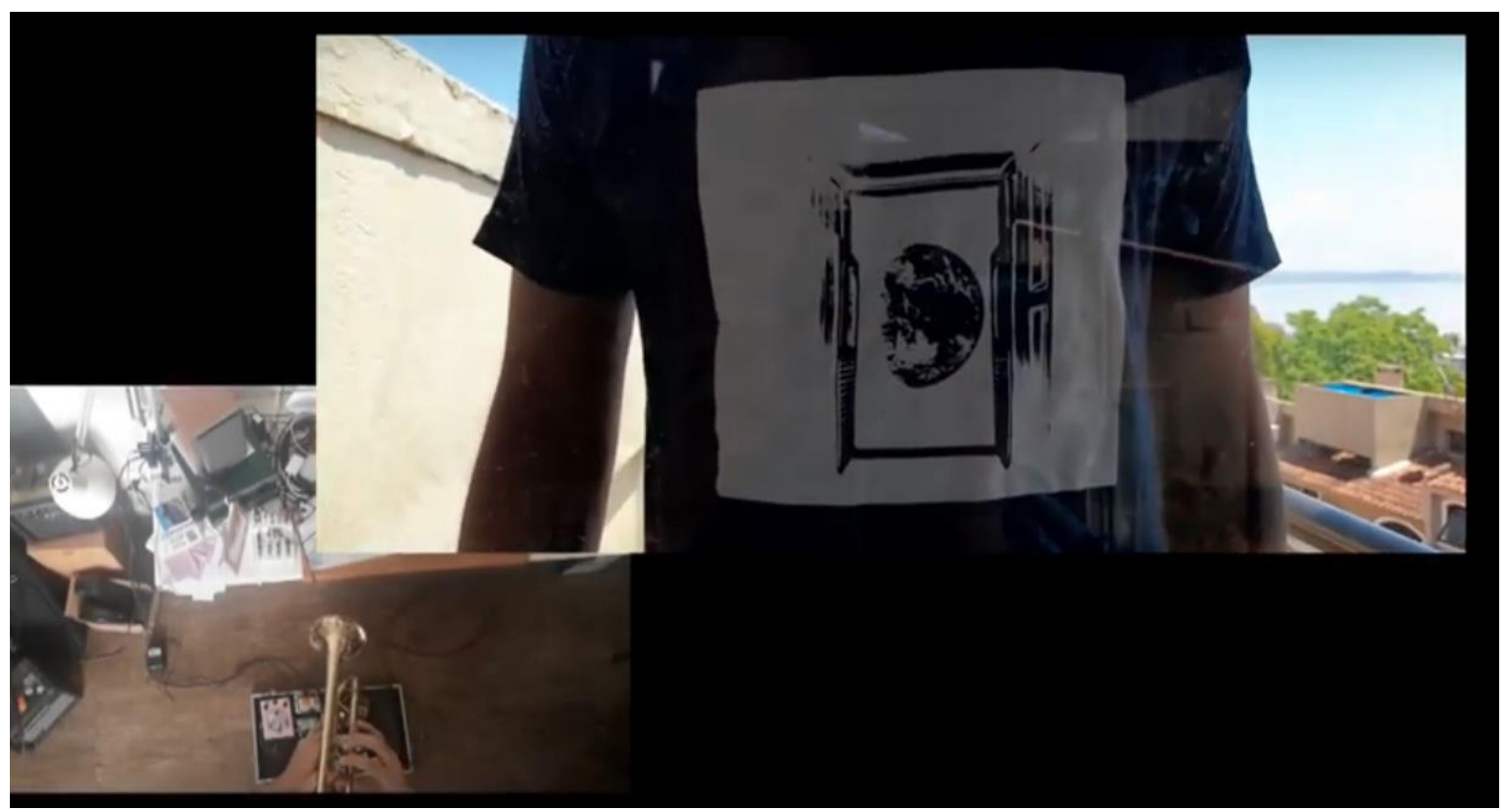

Quadro 1, selecionado da atividade realizada para a disciplina. ${ }^{5}$

Onde encontrar a conexão com a natureza?

Te convido a mirar por minha janela.

Da porta-janela de minha casa encontro minha maior relação com a natureza em tempos de isolamento: mirar-o-Guaíba.

Rio ou Lago. Corpo d'água, assim como o corpo humano, que também é água.

Água: Guaíba - corpo d'água; Água: 70\% do corpo;

\footnotetext{
${ }^{4}$ Todos os textos apresentados ao longo deste fragmento foram utilizados no trabalho realizado para a disciplina. Se encontram formatados de maneira centralizada, respeitando a formatação original. Contudo, o trabalho não foi aqui reproduzido na íntegra - não caberia fazê-lo pois, na collage, antes da cola é necessário o recorte.

${ }^{5}$ Elaborado pelo autor, para uso interno da disciplina.
}

TESSLER, Gustavo Monteiro. Corpo que cola, corpo que cria: ensaio-collage de um aprender somático em isolamento. Revista da FUNDARTE. Montenegro, p.01-18, ano 21, ํㅜ 44, janeiro/março de 2021.

Disponível em: http://.seer.fundarte.rs.gov.br/index.php/revistadafundarte/index> 30 de março de 2021. 


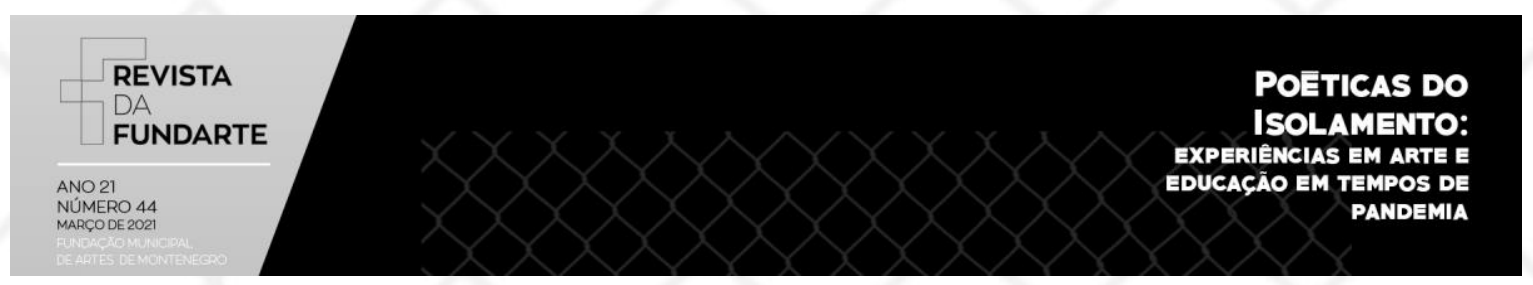

Improviso:

Toco comigo mesmo. O que mais sinto falta é de me encontrar com pessoas e tocar. Improvisar sozinho não tem graça.

A quem eu surpreendo sozinho?

Pedais de efeito: loop, loop, loop. Repetição.

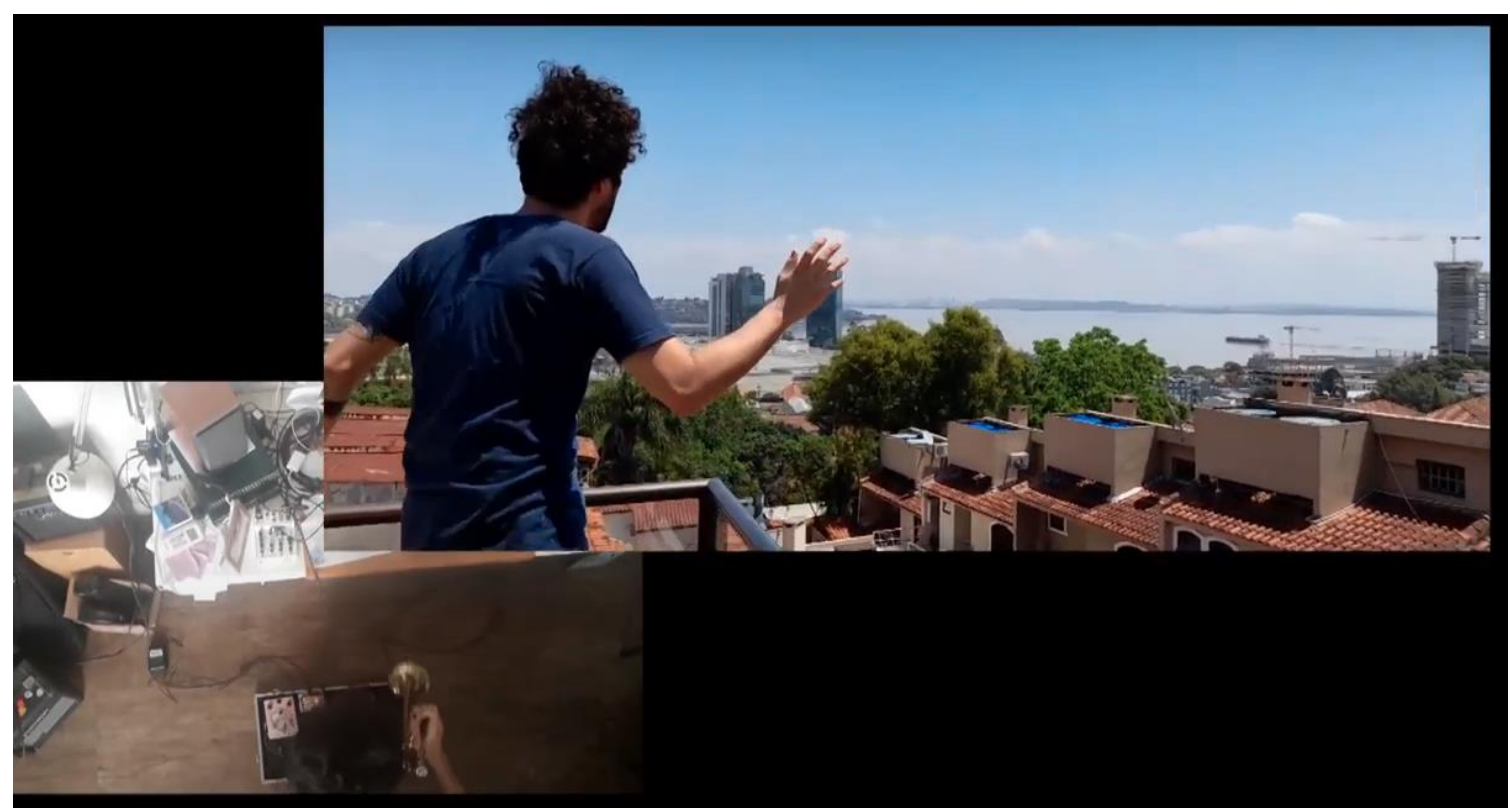

Quadro 2, selecionado da atividade realizada para a disciplina. ${ }^{6}$

Mesmo isolado, recebo interferência de muitas coisas.

Que prédio horroroso! Aquilo que chamam de progresso? Então sou um antiprogressista? Progressista pelo progresso? Por este progresso?

De que importa o título?

Rio ou lago: importa o título?

Pedais de efeito: delay, reverb, distorção.

\footnotetext{
${ }^{6}$ Idem.
}

TESSLER, Gustavo Monteiro. Corpo que cola, corpo que cria: ensaio-collage de um aprender somático em isolamento. Revista da FUNDARTE. Montenegro, p.01-18, ano 21, ํo 44, janeiro/março de 2021.

Disponível em: http://.seer.fundarte.rs.gov.br/index.php/revistadafundarte/index> 30 de março de 2021. 


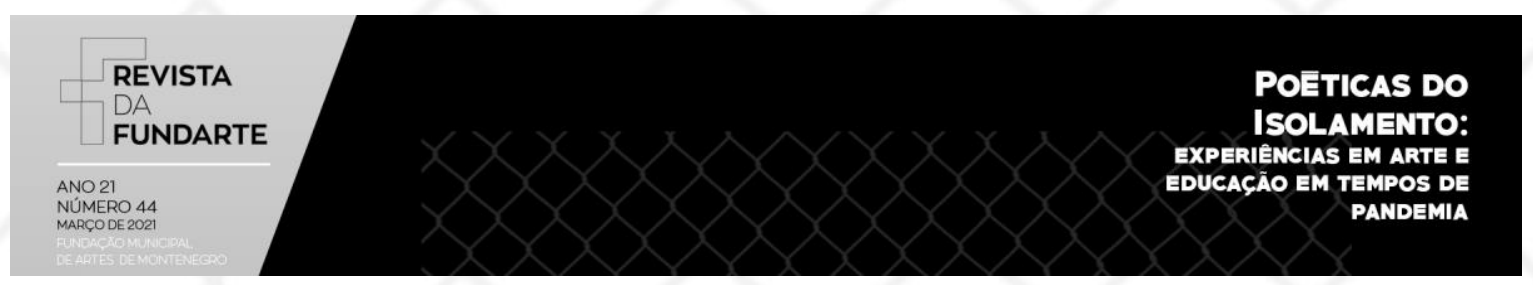

Que cidade é essa que eu vejo?

Te convido a dançar comigo.

Queria te convidar a tocar comigo.

Estou te mostrando o mais íntimo de mim: minha casa; meu movimento improvisado; a música repetida que sai de meus pulmões.

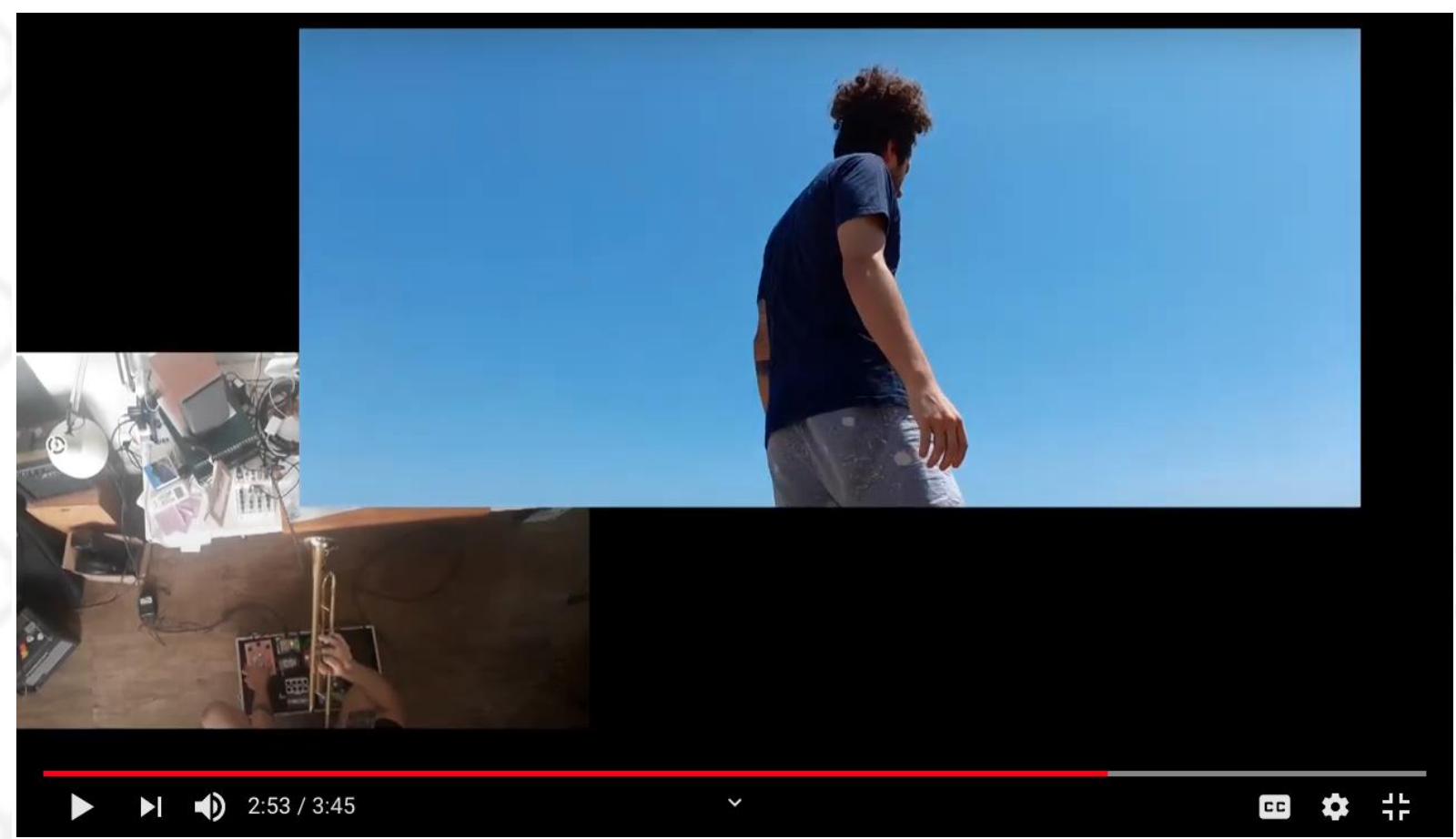

Quadro 3, selecionado da atividade realizada para a disciplina, apresentado com a barra de visualização que remete ao ambiente virtual. ${ }^{7}$

A janela da minha camiseta mostra o mundo.

A janela da minha casa me conecta com o mundo.

A janela do computador apresenta o meu mundo.

\footnotetext{
${ }^{7}$ Idem.
}

TESSLER, Gustavo Monteiro. Corpo que cola, corpo que cria: ensaio-collage de um aprender somático em isolamento. Revista da FUNDARTE. Montenegro, p.01-18, ano 21, ํo 44, janeiro/março de 2021.

Disponível em: http://.seer.fundarte.rs.gov.br/index.php/revistadafundarte/index> 30 de março de 2021. 


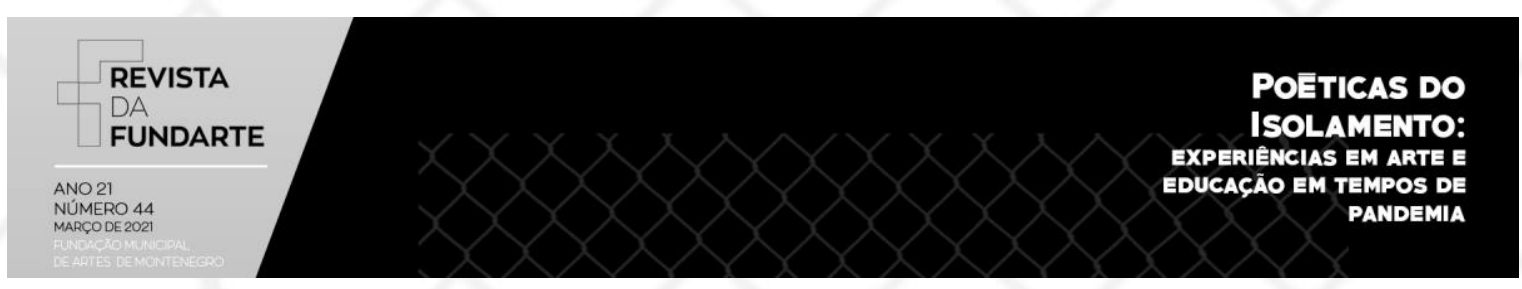

[cola]

O que passa, então, ao tensionarmos as faltas, buscando entendê-las enquanto metáforas? Há possibilidade de articularmos estas faltas justamente em direção ao transbordamento pretendido? Temos passado por tempos que nos obrigam a direcionar nossas práticas em educação através de modelos que não necessariamente são nosso chão. A própria opção de chamar o modelo atual de Ensino Remoto Emergencial já apresenta a questão através de sua etimologia: não é sinônimo de Educação a Distância - EaD - campo que possui seus estudos e aprofundamentos específicos. Docentes que hoje se colocam na condição de experimentar o ensino remoto não necessariamente passaram por uma formação específica neste campo. Ao mesmo tempo, discentes também não necessariamente possuem as disponibilidades específicas que possibilitam este tipo de ensino. Ou seja, na prática, tudo vem a ser experimental. Toda aula no modelo ERE é laboratório, é ensaio.

Assume-se esta característica laboratorial de nossos presentes ambientes virtuais de ensino para se propor, então, potências de criação. Conforme sugere Luciana Loponte:

Reconhecer que o conhecimento é abastecido por metáforas que associam arbitrariamente determinadas palavras e conceitos às coisas, nos reaproxima da arte e da criação, tão desvalorizada secularmente pela racionalidade da civilização ocidental. (LOPONTE, 2019, p. 485).

Mais do que apenas uma possibilidade, assumir a potência inventiva da criação artística na educação é agora um artifício para nos mantermos com empenho mesmo em meio a tempos que nos distanciam de nossos lugares de tranquilidade. Se as condições de vida nos tiraram do conforto e nos fizeram assumir perspectivas inesperadas, cabe a nós transformarmos esta energia em criação.

Foi justamente neste sentido que desenvolveu-se o trabalho final da disciplina de Estudos Somáticos do Movimento. Após um semestre diferente, com muitas faltas, algumas sobras e um número incontável de transformações, nos encontrávamos em uma situação de pôr em dúvida tudo o que vínhamos estudando.

TESSLER, Gustavo Monteiro. Corpo que cola, corpo que cria: ensaio-collage de um aprender somático em isolamento. Revista da FUNDARTE. Montenegro, p.01-18, ano 21, ํㅡㄴ, janeiro/março de 2021.

Disponível em: http://.seer.fundarte.rs.gov.br/index.php/revistadafundarte/index> 30 de março de 2021. 


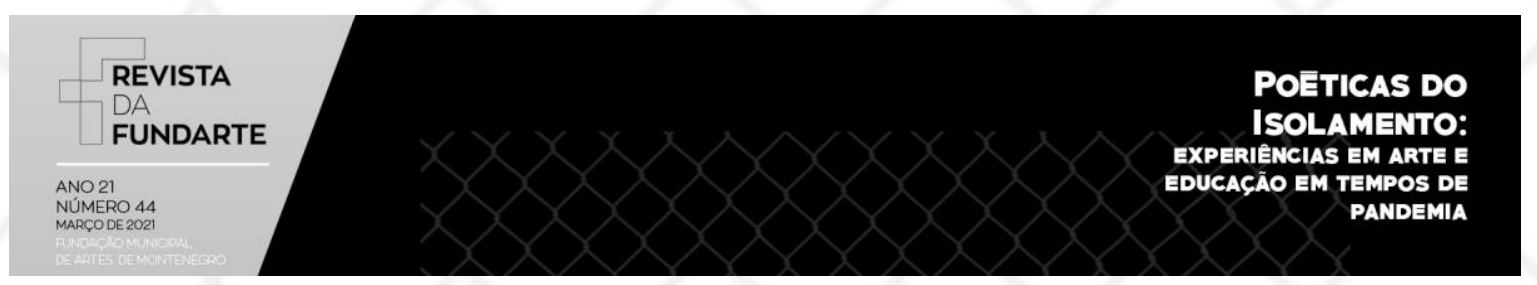

Entendendo que não se tratava, pois, de uma sistematização dos conteúdos abordados ao longo das aulas, mas sim de um momento de criação potente, a professora responsável pela disciplina realizou um movimento de horizontalizar o planejamento e se colocar em um mesmo nível do corpo discente, se propondo a experimentar no coletivo. Desta forma, ficamos nós, corpos discente e docente, com o desafio de se deixar transformar - e, sobretudo, inventar.

Desta maneira, manifestou-se a vontade coletiva de se produzir, ainda que virtualmente, encontros. Não os mesmos encontros por videochamada que já aconteciam, mas encontros outros possíveis. Passamos, então, ao exercício de encontrar ideias, tentando mapear quais os lugares onde chegávamos a partir destes encontros. Em um certo momento, percebeu-se que talvez o eixo central dos estudos realizados ao longo do semestre estivesse a um alcance mais palpável que o imaginado: os próprios corpos. Observou-se que tudo que foi lido, praticado, exercitado tinha vibrado justamente nos corpos. Cada um à sua maneira, respeitando suas especificidades.

Como, então, criar? E para onde direcionar esta criação? Estas perguntas surgiram antes mesmo de se questionar o que especificamente estávamos criando. Foi talvez neste momento em que nos demos conta que só de estarmos produzindo estes encontros, estas ideias, já estávamos criando. Voltar-se ao corpo, ao longo dos estudos que realizamos no campo da somática, significava, para nós, entender como tudo aquilo nos fazia sentido naquele momento.

Para tanto, como possibilidade inventiva e ambiente dos encontros possíveis, uma vez mais nos voltamos ao artifício dos vídeos. Desta vez, nos propomos a construir um vídeo coletivamente, através de vários vídeos produzidos de maneira individual. Vídeos contendo movimentos cotidianos dos corpos que os produzem. Como apresentação, materialidade da produção final, realizamos um trabalho de colagem e sobreposição dos vídeos produzidos individualmente. Desta maneira, produzimos os encontros possíveis e nos sujeitamos a novas perspectivas de se deixar afetar uns corpos pelos outros. Interessante destacar, também, que ao

TESSLER, Gustavo Monteiro. Corpo que cola, corpo que cria: ensaio-collage de um aprender somático em isolamento. Revista da FUNDARTE. Montenegro, p.01-18, ano 21, ํㅡㄴ, janeiro/março de 2021.

Disponível em: http://.seer.fundarte.rs.gov.br/index.php/revistadafundarte/index> 30 de março de 2021. 


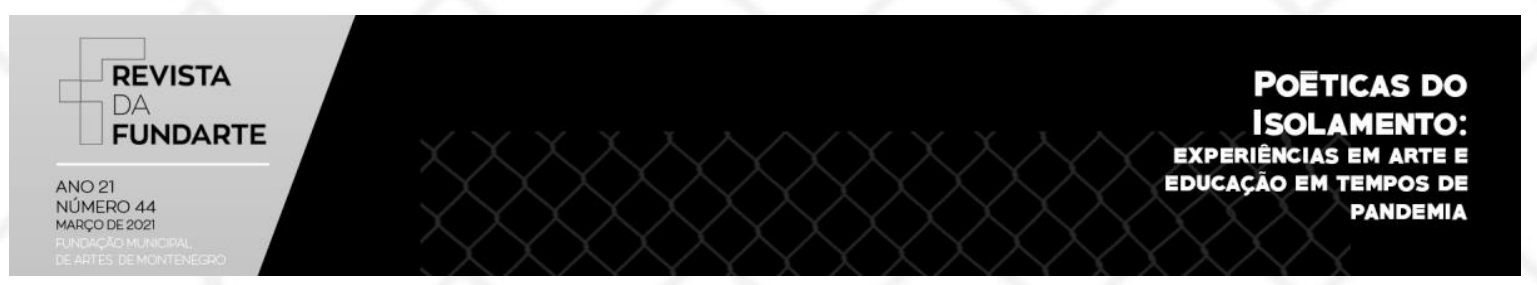

sobrepor as imagens de diversas casas, promovemos também os encontros entre estes espaços, subvertendo às geografias rígidas. Outra subversão interessante foi a de por vezes, através da edição do vídeo, sobrepor as imagens de um mesmo corpo, possibilitando encontros consigo mesmo, anteriormente impossíveis - e que serão observados pelo corpo através de uma tela-janela, adquirindo mais um significado.

Como trilha Sonora, utilizamos registros em áudio de nossas conversas que ocorreram ao longo da disciplina, sobretudo aproveitando mensagens de áudio, enviadas por aplicativos de conversa, nas quais falávamos sobre o trabalho final em si. "Estou confusa", "alguém está entendendo?" e "onde é que a gente vai chegar, hein?" foram algumas das frases que, ao passar do recorte para a cola, adquiriram novo significado, partindo da dúvida em relação ao caminho e constituindo-se como o próprio caminho em si. A edição final do vídeo foi gentilmente realizada por uma colega, após conversas com a turma. Interessante ressaltar a dinâmica que optamos em transformar todas as conversas sobre o trabalho no trabalho em si. Desta forma, a construção se deu de maneira contínua.

Seguido da realização do vídeo, iniciamos a produção de um texto, também coletivamente. Buscamos, através da escrita, cartografar nossos anseios, da maneira mais ampla possível. Nos orientamos através de algumas perguntas, como: o que esperávamos da disciplina? Como foi a experiência de virtualizar os encontros? Como foi, observar-se no vídeo coletivo? E, da mesma maneira que ocorreu nos áudios sobre o trabalho, onde é que a gente vai chegar, hein?

Segue agora uma nova collage, um novo experimento. Neste fragmento, apresenta-se o encontro de partes deste processo. Misturam-se recortes do texto, com quadros do vídeo. Apresenta-se então, como reverberação daquele trabalho contínuo, que seguiuu existindo na medida em que me propus a escrever sobre, e que ressignifica seu existir na medida em que o presente ensaio é lido.

TESSLER, Gustavo Monteiro. Corpo que cola, corpo que cria: ensaio-collage de um aprender somático em isolamento. Revista da FUNDARTE. Montenegro, p.01-18, ano 21, ํㅡㄴ, janeiro/março de 2021.

Disponível em: http://.seer.fundarte.rs.gov.br/index.php/revistadafundarte/index> 30 de março de 2021. 


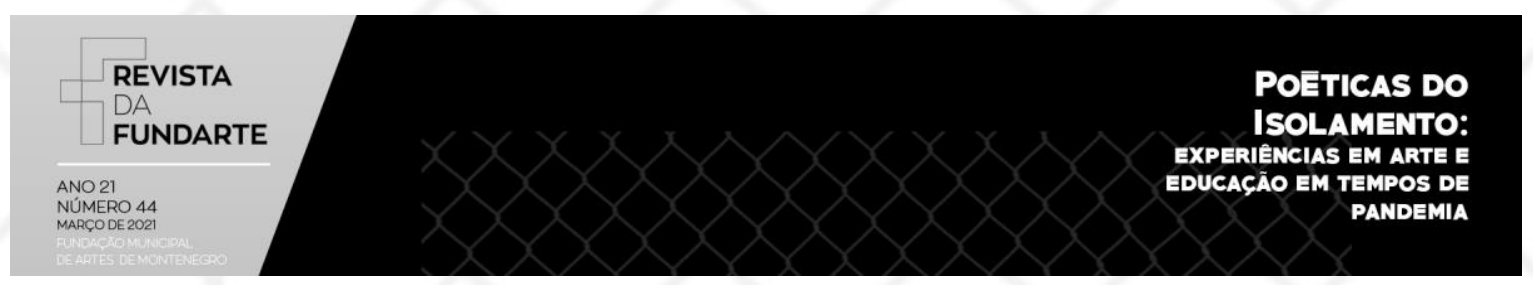

Fragmento-escrita-imagem: por várias mãos. ${ }^{8}$

[atenção: escrita sobreposta]

existe dupla-exposição

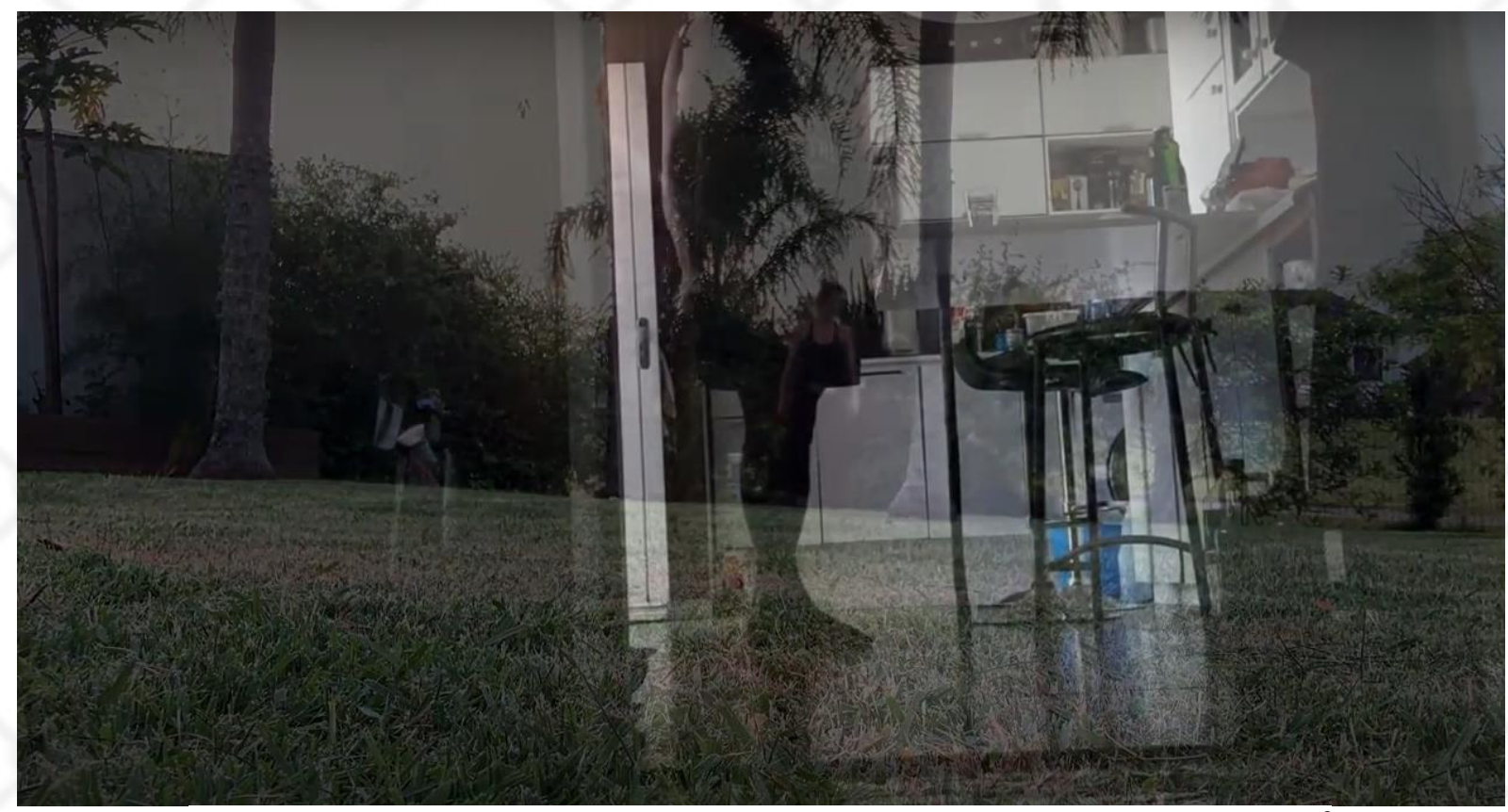

Quadro 4, apresentando dois corpos e dois espaços em encontro sobreposto. ${ }^{9}$

A gente já tem um caminho?

Importa onde queremos chegar ou qual o caminho a percorrer?

Há quase 9 meses minha maior companheira é uma cadeira: ESCREVO-DA-

CADEIRA-PARA-SER-LIDO-DE-OUTRA-CADEIRA-E-COMENTADO-COM-OUTRA-

CADEIRA - MAS TEM QUEM PREFIRA O CHÃO - E TUDO BEM.

8 Os textos presentes neste fragmento foram produzidos de maneira coletiva pelos corpos que compunham a turma. Seu uso, bem como o das imagens, foi autorizado para o presente trabalho. A formatação respeita a maneira que foi pensada coletivamente. Optou-se por reproduzir os escritos todos em itálico para indicar que foram retirados desta produção coletiva.

${ }^{9}$ Elaborado coletivamente pela turma, com edição final de Chana Manica, como parte do trabalho final da disciplina.

TESSLER, Gustavo Monteiro. Corpo que cola, corpo que cria: ensaio-collage de um aprender somático em isolamento. Revista da FUNDARTE. Montenegro, p.01-18, ano 21, ํㅡ 44, janeiro/março de 2021.

Disponível em: http://.seer.fundarte.rs.gov.br/index.php/revistadafundarte/index> 30 de março de 2021. 

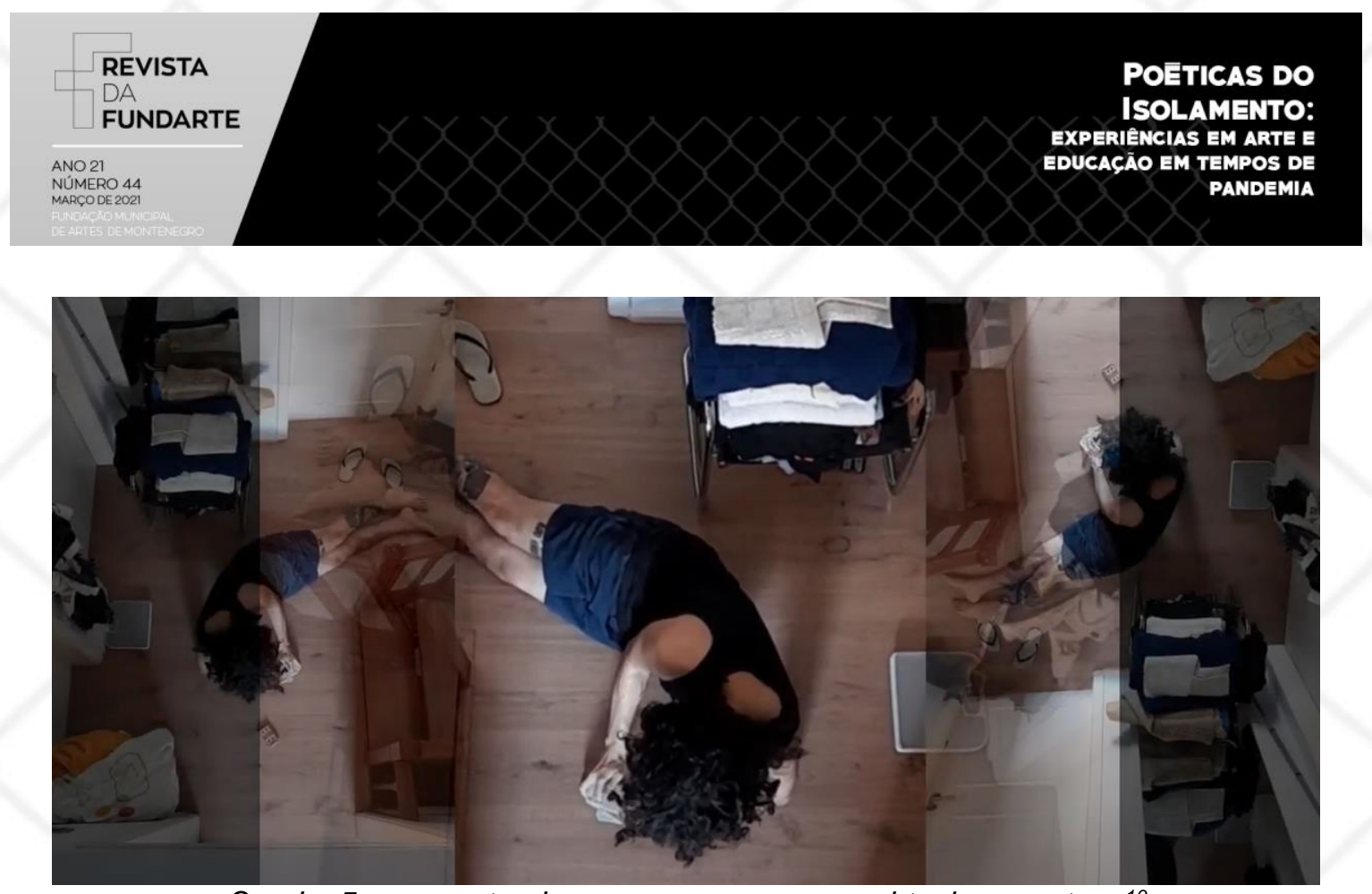

Quadro 5, apresentando um mesmo corpo em virtuais encontros. ${ }^{10}$

Do meio de meu dia virtual lembro que preciso assistir ao vídeo. Como era mesmo?

Por um momento acreditava que o vídeo estava arrastado demais. Experimento a lentidão, me proponho a ela. Me proponho a doar alguns minutos do meu dia para assistir ao vídeo. Me proponho a doar 24 horas por dia para ser meu corpo.

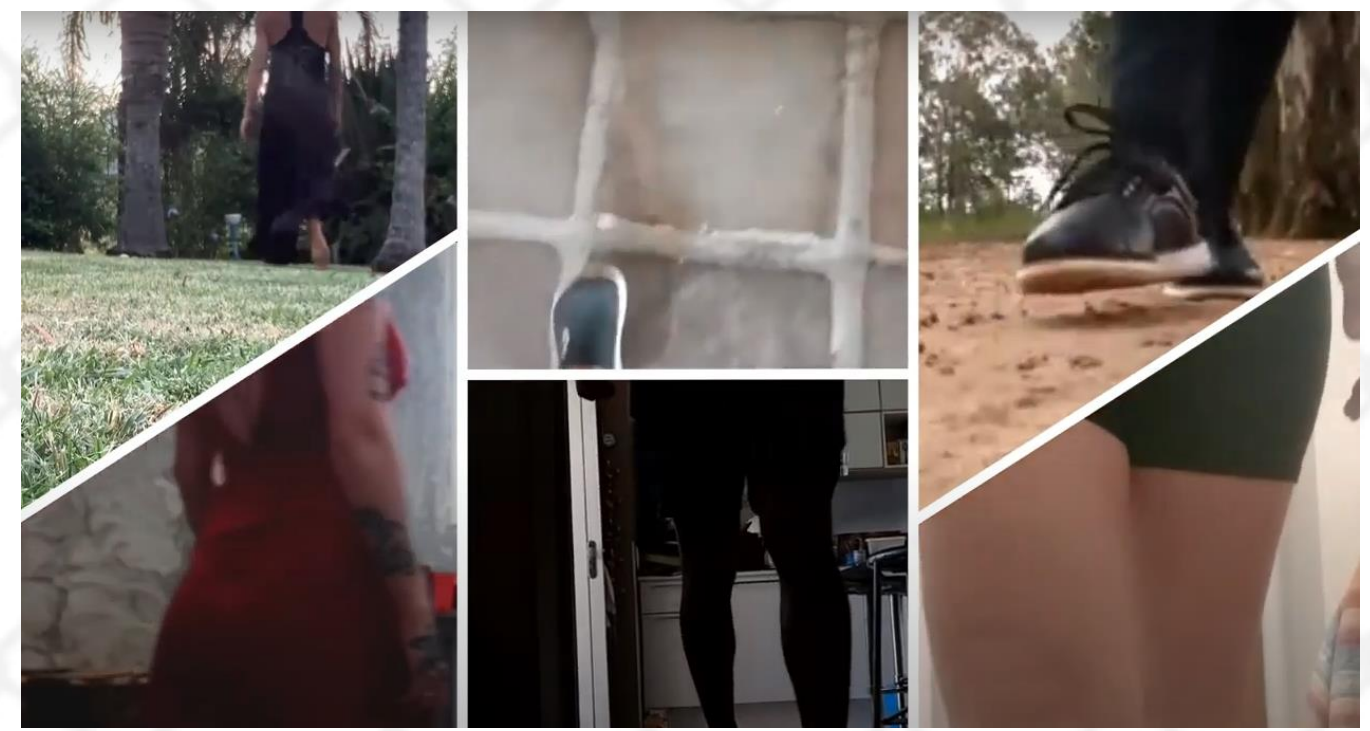

Quadro 6, apresentando uma collage de pernas, pés, troncos, caminhos. ${ }^{11}$

\footnotetext{
10 Idem.
}

TESSLER, Gustavo Monteiro. Corpo que cola, corpo que cria: ensaio-collage de um aprender somático em isolamento. Revista da FUNDARTE. Montenegro, p.01-18, ano 21, ㄲo 44, janeiro/março de 2021.

Disponível em: http://.seer.fundarte.rs.gov.br/index.php/revistadafundarte/index> 30 de março de 2021. 


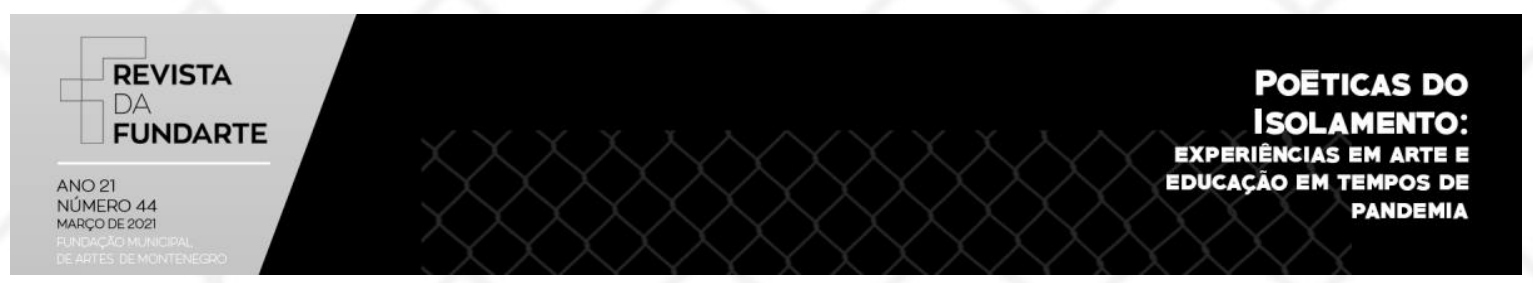

- Em vocês senti a vontade... é isso? - Sim, alguma coisa acontece!

\section{Fragmento-[cola]}

Carta à professora: 12

\section{Carta ao corpo:}

Busquei esta disciplina numa tentativa de retornar ao meu corpo, mais uma vez. Sigo tentando construir caminhos somáticos em mim mesmo.

Apenas já matriculado na disciplina que fui conhecer e iniciar meu processo de entendimento sobre a Prática como Pesquisa (FERNANDES, 2014) - e que privilégio poder começar a pensar nisso justamente de maneira prática! E é por aí que me pego refletindo sobre todas essas possibildiades e despossibilidades de ensino que temos como realidade hoje. Também todas essas possibilidades e despossibilidades de corpo.

Tento ao máximo pensar mais nos transbordamentos. Ao longo do semestre, fomos prática não só como pesquisa, mas como resgate. Pelas janelas virtuais nos conectamos com coletivo; pelas janelas físicas, com o mundo. Resgatamos o corpo, pelo corpo, com o corpo. Mas não com os corpos - olho no olho apenas quando a internet permitiu.

Ao longo do semestre, acredito que meu maior movimento, minha maior prática, foi no sentido de entender que não vivemos uma relação de antes ou depois - da pandemia. Vivemos um agora constante. Está em nossas mãos, em nosso corpo construir as dinâmicas de existência que definirão como será o futuro. Penso que sempre fomos nós que definimos o que vem depois. Com o advento da pandemia e dos isolamentos sociais, me parece que identificar esta potência é o que nos coloca em movimento, o que nos distancia de uma paralisia (ESPINOSA, 2020).

\footnotetext{
11 Idem.

$12 \mathrm{O}$ presente fragmento deriva de uma mensagem enviada à professora ao término das aulas. À Cibele Sastre, gracias por todas as trocas, todos os ensinamentos - na somática, na docência, na vida.
}

TESSLER, Gustavo Monteiro. Corpo que cola, corpo que cria: ensaio-collage de um aprender somático em isolamento. Revista da FUNDARTE. Montenegro, p.01-18, ano 21, ํㅡㄴ, janeiro/março de 2021.

Disponível em: http://seer.fundarte.rs.gov.br/index.php/revistadafundarte/index> 30 de março de 2021. 


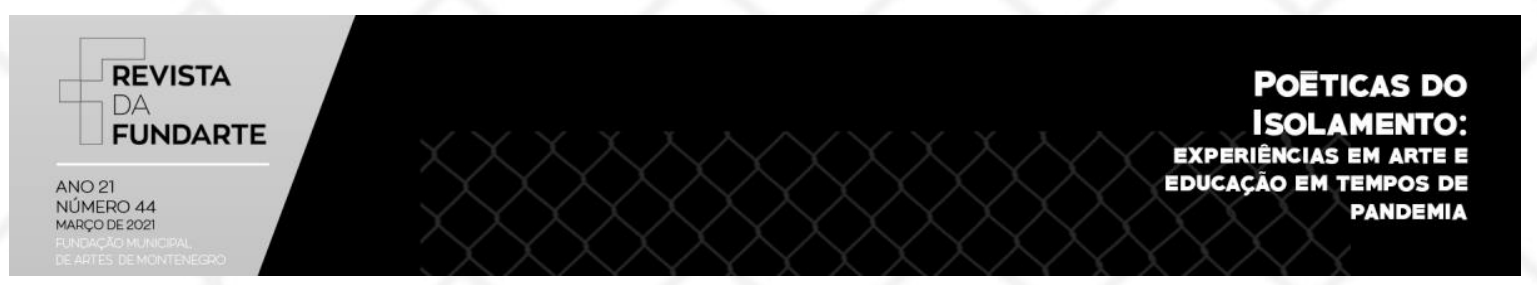

Mais ainda, é o que pode definir de que maneira podemos nos projetar ao que vem por aí.

Novamente reforço: não podemos aguardar passivamente pelo futuro, pois ele nos machucaria em várias possibilidades. A curto prazo, nos angustia, não chega nunca. A longo prazo, nos frustra, pois certamente não será da maneira que esperamos. Subvertamos esta passividade: criemos!

Demorei a me entender como professor. Mas e habitando uma sociedade onde é tão normal falar de educação sem conhecê-la, sem estudá-la, comecei a pensar na necessidade de me afirmar dentro deste campo. Se é minha especialidade, minha área de conhecimento, devo sim me afirmar perante a mesma. Me reconheço, então, como professor. Sou professor!

Como buscar o afeto que cria nos corpos as potências em existir? Mesmo que na Geografia, como aprender com [pelo e para] o corpo? Como criar, então, em minhas aulas possibilidades de dança? Encerro este ensaio sem muitas certezas, mas com umas várias novas dúvidas. Não poderia deixar de citar uma passagem de Ensinando a transgredir, de bell hooks (2013). O livro é dedicado à memória de O'Neal LaRon Clark, aluno de bell hooks que veio a falecer. Em uma bonita passagem, a autora remete ao sentimento do aluno de encontrar a beleza de suas aulas ao relacioná-las, justamente com a dança. E é esta a mensagem de criação que utilizo para colar todo o resto que foi aqui apresentado:

\begin{abstract}
"Adoro dançar. Quando era menino, dançava em qualquer lugar. Por que ir andando até lá quando eu podia gingar e bambolear caminho afora? Quando eu dançava, minha alma se libertava. Eu era poesia. [...] Quando danço, minha alma é livre. É triste ler sobre homens que param de dançar, que param de ser tolos, que param de deixar que suas almas voem livres... Acho que, para mim, sobreviver inteiro significa nunca parar de dançar." O'Neal LaRon Clark, em Ensinando a Transgredir. (hooks, 2013, p. 261).
\end{abstract}

Dancemos. Bamboleemos até o futuro que por nós será praticado. Duvidando, sempre, mesmo do mais simples andar.

TESSLER, Gustavo Monteiro. Corpo que cola, corpo que cria: ensaio-collage de um aprender somático em isolamento. Revista da FUNDARTE. Montenegro, p.01-18, ano 21, ํo 44, janeiro/março de 2021.

Disponível em: http://seer.fundarte.rs.gov.br/index.php/revistadafundarte/index> 30 de março de 2021. 


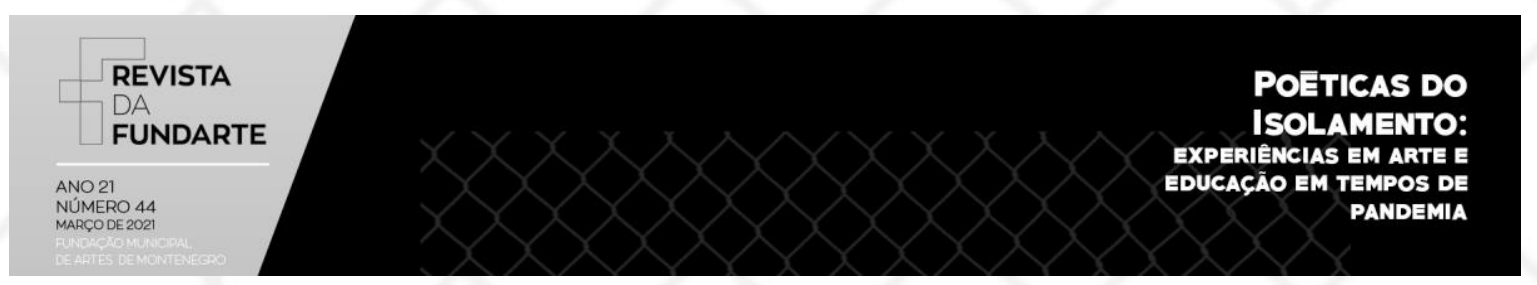

\section{Referências:}

CATALÃO, Vera Margarida Lessa. A redescoberta do pertencimento à natureza por uma cultura da corporeidade. Terceiro incluído - NUPEAT-IESA-UFG, v.1, n.2, jul./dez./2011, p.74 -81, Artigo 12

ESPINOSA, Baruch de, 1632-1677. Breve tratado de Deus, do homem e do seu bem-estar - 2. ed. - Belo Horizonte : Autêntica Editora, 2020.

Fernandes, Ciane. Im(v)ersões corpo ambiente e a criação coreo-videográfica. In: Revista Cena. Porto Alegre, n. 13, 2013.

A Prática como Pesquisa e a Abordagem Somático-Performativa. Anais ABRACE, v. 15, n. 1. VIII Congresso da ABRACE. Belo Horizonte: UFMG, 2014.

FOUCAULT, Michel, 1926-1984. História da sexualidade 2; o uso dos prazeres. Rio de Janeiro: Edições Graal, 1988.

FUÃO, Fernando Freitas. A collage como trajetória amorosa / Fernando Freitas Fuão. - Porto Alegre: Editora da UFRGS, 2011.

hooks, bell. Ensinando a transgredir: a educação como prática da liberdade. São Paulo: Editora WMF Martins Fontes, 2013.

LATOUR, Bruno. Como falar do corpo? A dimensão normativa dos estudos sobre ciência. In: NUNES, João Arriscado; ROQUE, Ricardo (org). Objectos Impuros: Experiências em Estudos sobre a Ciência. Porto: Edições Afrontamento e autores, 2008, p. 39-61.

LISPECTOR, Clarice, 1925-1977. A hora da estrela / Clarice Lispector. - Rio de Janeiro: Rocco, 1998. 1를 edição.

LOPONTE, Luciana Gruppelli. Arte, verdade e pesquisa em educação. In: ETD Educação Temática Digital, Campinas, SP, v. 21, n. 2, p. 479-494, 2019.

ROLNIK, Suely. Cartografia Sentimental: transformações contemporâneas do desejo. $2^{\underline{a}}$ edição, Porto Alegre: Sulina; Editora da UFRGS, 2016.

SMITH, Patti. Devoção. São Paulo: Companhia das Letras, 2019.

VENDRAMIN, Carla; CHRISTIE, Kimberly. Processos vivenciais de um permaculturar dançande \#EMCASA. Ensasios textuais, fotográficos e audiovisuais públicados para o coletivo fleuma. Campinas, 2020. Disponível em: $<$ https://coletivofleuma.wordpress.com/2020/10/07/processos-vivenciais-de-umpermaculturar-dancante-emcasa/>. Acesso em: 03. fev. 2021.

TESSLER, Gustavo Monteiro. Corpo que cola, corpo que cria: ensaio-collage de um aprender somático em isolamento. Revista da FUNDARTE. Montenegro, p.01-18, ano 21, ㄲo 44, janeiro/março de 2021.

Disponível em: http://.seer.fundarte.rs.gov.br/index.php/revistadafundarte/index> 30 de março de 2021. 